\title{
Suitability of Groundwater Quality for Irrigation Purpose using Geographical Information System: A Case Study of Durg Block Chhattisgarh
}

\author{
Lov Kumar Gupta ${ }^{1 *}$, Kapil Verma ${ }^{2}$ and Shruti Verma ${ }^{2}$ \\ ${ }^{1}$ Soil and Water Engineering, ${ }^{2}$ Farm Machinery and Power Engineering, \\ Masturi, Bilaspur, Chhattisgarh-495551, India \\ *Corresponding author
}

A B S T R A C T

\section{Ke y w o r d s \\ Electrical \\ Conductivity, \\ Residual Sodium \\ Carbonate, Sodium \\ Ratio,Kelly's \\ Index,Permeability \\ Index}

Article Info

Accepted:

15April 2020

Available Online:

10 May 2020
An attempt has been made to understand the ground water quality and its suitability for irrigation purpose through Geographical Information System. The qualities of groundwater in $646.8 \mathrm{~km} 2$ area of Durg block were assessed for its suitability for irrigation purposes. Groundwater samples data are analyzed for ionic concentration of $\mathrm{CO}_{3}{ }^{2}, \mathrm{HCO}_{3}^{-}, \mathrm{CI}^{-}, \mathrm{SO}_{4}{ }^{2-}, \mathrm{Ca}_{2}, \mathrm{Mg}_{2}{ }^{+}, \mathrm{Na}^{++}$and $\mathrm{K}^{+}$. Parameters such as electrical conductivity (EC), sodium absorption ratio (SAR), $\% \mathrm{Na}$ and residual sodium carbonate (RSC) were evaluated. Thematic maps of different parameters were prepared and Samples were plotted on US Salinity Diagram and H. Wilcox's Diagram for better understanding of suitability of groundwater for irrigation purpose. The EC values of water samples were found to be within good to permissible limits. The lowest EC in groundwater samples was observed in Bhilai $(554 \mu \mathrm{S} / \mathrm{cm})$ and the highest in Durg $(1593 \mu \mathrm{S} / \mathrm{cm})$. The output of SAR shows 100 percent of the samples fall under excellent to good category. The irrigational water quality was classified based on US salinity diagram indicating that in 4 samples fall under low to moderate saline and 6 samples fall under low to medium high salinity. The Wilcox diagram shows 4 samples fall under excellent to good category and 6 samples fall under good to permissible category. Samples were analyzed for water quality parameters like \% Na, PI, RSC and KI and suitability of groundwater samples for irrigation is good to permissible in almost all cases. Contour maps of $\mathrm{pH}, \mathrm{EC}, \mathrm{SAR}, \% \mathrm{Na}$ and $\mathrm{RSC}$ were plotted to study spatial variability of these parameters in the block which is helpful to assess the irrigational water quality of study area.

\section{Introduction}

Ground water is the water present beneath Earth's surface in soil pore spaces and in the fractures of rock formations. Groundwater has become the major source of water supply for domestic, industrial and agricultural sectors of our country. It constitutes about two thirds of the fresh water resources of the world. In India, it is a major source for all purposes of water requirements. It plays a vital role in the country's economic development and in ensuring its food security. More than $90 \%$ of rural and nearly $30 \%$ of urban population depend on ground water for drinking water. It also accounts for nearly $60 \%$ of the total 
irrigation potential in the country. Groundwater plays an important role in Indian agriculture. The suitability of irrigation water depends upon many factors including the quality of water, soil type, salt tolerance characteristics of the plants, climate and drainage characteristics of the soil.

The quality of groundwater is deteriorating due to urbanization, increasing population, and agricultural chemicals. In addition, the civil works, landslides, and the change in the rate of rain infiltration into ground water are affecting the quality adversely (Ramesh and Elango, 2012). Groundwater always contains small amount of soluble salts dissolved in it.

The kind and quality of these salts depend upon the sources for recharge of the groundwater and the strata through which it flows. The excess quantity of soluble salts may be harmful for many crops. Hence, a better understanding of the chemistry of groundwater is very essential to properly evaluate groundwater quality for irrigation purpose.

Demand of groundwater has been increasing day by day for irrigation by bringing more area under cultivation. The chemical composition of water is an important factor for domestic or irrigation purposes. Salinity and Pollution of well water, either from point or non-point sources, has become a thing of health concern both in urban and rural areas.

Features that generally need to be considered for evaluation of the suitability of groundwater quality for irrigation are the EC, SSP, TDS, RSC and SAR. The Most important cation and anion in a groundwater resources are $\mathrm{Ca}^{2+}, \mathrm{Mg}^{2+}, \mathrm{Na}^{+}, \mathrm{HCO}^{3-}, \mathrm{Cl}^{-}$and $\mathrm{NO}^{3-}$. Suitability of irrigation water, with respect to salinity, is assessed on the basis of the 'Electrical Conductivity' (EC) or 'specific conductance' of a water sample.
Salts in soil or water reduce water availability to the crop and excessive nutrients reduce yield or quality. A Geographical Information System (GIS) is a system of hardware, software and procedures to facilitate the management, manipulation, analysis, modeling, representation and display of geo- referenced data to solve complex problems regarding planning and management of resources. Functions of GIS include data entry, data display, data management, information retrieval and analysis.

Geographic information system (GIS) has emerged as a powerful tool for storing, analyzing, and displaying spatial data and using these data for decision making in several areas including engineering and environmental fields (Stafford 1991; Goodchild 1993; Burrough and McDonnell 1998; Lo and Yeung 2003).Conventional surveys, apart from being unfeasible in the inaccessible and inhospitable terrain are tedious, time consuming and inaccurate in mapping many features of regional nature due to lack of regional perspective.

GIS have been increasingly used for recharge estimation, draft estimation, mapping of prospective Zones, identification of over exploited and under developed/ undeveloped areas and prioritization of areas for recharge structures which conjunctively facilitate systematic planning, development and management of ground water resources on a sustainable basis.

The spatial distribution maps generated for various physicochemical parameters using GIS techniques could be useful for planners and decision makers for initiating ground water quality development in the area. The knowledge of irrigation water quality is critical to understand what management changes are necessary for long-term and 
short-term productivity, particularly for crops that are sensitive to changes in quality with an adequate database, GIS can be a powerful tool for assessing water quality, developing solutions for water resource problems, and it is a decision-making tool for agriculture development.

\section{Materials and Methods}

\section{Description of study area}

The study area is in the western central part of Chhattisgarh, dist. Durg and bounded by the coordinates $21^{\circ} 1^{\prime} 40.55^{\prime \prime} \mathrm{N}$ to $21^{\circ} 21^{\prime} 56.03^{\prime \prime} \mathrm{N}$ latitude and $81^{\circ} 8^{\prime} 53.88^{\prime \prime} \mathrm{E}$ to $81^{\circ} 25^{\prime} 37.02^{\prime \prime} \mathrm{E}$ longitude. It covers total geographical area $646.8 \mathrm{~km}^{2}$. Climate of the study area is tropical type.

Summer is a little bit hotter. Rise of temperature begins from the month of March to May. May is hottest amongst other. Annual average rainfall is $1052 \mathrm{~mm}$. During the year, most rainfall occurs during the monsoon June to September. July is the month of highest rainfall.

Survey of India (SOI) toposheets (f44p3, $\mathrm{f} 44 \mathrm{p} 4, \mathrm{f} 44 \mathrm{p} 7$ and $\mathrm{f} 44 \mathrm{p} 8$ in 1:50000 scale) were used for the preparation of the base map. For analyzing the chemical aspects of groundwater in the study area, observation wells have been selected for investigation.

These observation wells are regularly maintained by CGWB NCCR Raipur Chhattisgarh. Water quality data are utilized in the present study to analyze the groundwater chemistry.

Samples are analyzed in the laboratory of NCCR Raipur Chhattisgarh for the major ions chemistry employing standards methods. The range of analyzed parameters presented in table-1.
Important parameters for determining the suitability of groundwater for irrigation purposes

\section{Sodium adsorption ratio}

It indicates the degree to which irrigation water tends to enter into cation-exchange reactions in soil. Sodium replacing adsorbed calcium and magnesium is a hazard as it causes damage to the soil structure and becomes compact and impervious. SAR is defined as:

$$
\mathrm{SAR}=\frac{\mathrm{Na}}{\sqrt{(\mathrm{Ca}+\mathrm{mg}) / 2}}
$$

Where, all the ionic concentrations are in meq/l.

\section{Percent Na}

Sodium concentration plays an important role in evaluating the groundwater quality for irrigation as sodium increases the hardness of the soil and reduces its permeability. The SSP values are calculated using the formula given below:

$$
\% \mathrm{Na}=\frac{(\mathrm{Na}+\mathrm{K}) * 100}{\mathrm{Ca}+\mathrm{Mg}+\mathrm{Na}+\mathrm{K}}
$$

Where, all ionic concentrations are expressed in meq/l.

\section{Residual sodium carbonate (RSC)}

An excess amount of sodium bi-carbonate and carbonate is considered to be detrimental to the physical properties of soils as it causes dissolution of organic matter in the soil, which in turn leaves a black stain on the soil surface on drying. This excess amount is denoted by Residual Sodium Carbonate (RSC) and is calculated by the following formula: 
$\mathrm{RSC}=\left(\mathrm{HCO}_{3}^{-}+\mathrm{CO}_{3}^{--}\right)-\left(\mathrm{Ca}^{++}+\mathrm{Mg}^{++}\right)$

where, all the ionic concentrations are expressed in meq/l.

\section{Kelly's index (KI)}

In Kelly's Ration (KR), sodium is measured against calcium and magnesium to determine the suitability of irrigation water. When KI is $>1$, it indicates higher sodium and vice versa. $\mathrm{KI}$ is calculated by using the formula:

$$
\mathrm{KI}=\frac{\mathrm{Na}}{\mathrm{Ca}+\mathrm{Mg}}
$$

where, all ionic constituents are expressed in meq/l.

\section{Permeability index (PI)}

The soil permeability is affected by long-term irrigation influenced by $\mathrm{Na}+, \mathrm{Ca} 2+, \mathrm{Mg} 2+$ and $\mathrm{HCO} 3$ contents of the soil. The permeability index values also indicate the suitability of groundwater for irrigation. PI is calculated as follows:

$$
\mathrm{PI}=\frac{\left(\mathrm{Na}+\sqrt{\mathrm{HCO}_{3}}\right) * 100}{\mathrm{Ca}+\mathrm{Mg}+\mathrm{Na}}
$$

Where, all ionic concentrations are expressed in $\mathrm{meq} / \mathrm{l}$.

\section{Results and Discussion}

In present study, it has been found that the $\mathrm{pH}$ in the study area has shown variation from 7.3 to 8 Almost all samples were within maximum permissible limit prescribed by BIS for study area. Electrical Conductivity in groundwater varies from 554 to $1400 \mu \mathrm{s} / \mathrm{cm}$. Values of SAR, \% Na, RSC, KI and PI highest in Marauda. Classification of Samples according to Standards specified for Water
Quality Indices shows, for EC $40 \%$ samples fall under good category and $60 \%$ samples are fall under permissible range. $\% \mathrm{Na}$ values of study area $30 \%$ sample fall under Excellent, $60 \%$ under good and $10 \%$ samples are fall under permissible class. The values of SAR, RSC, KI and PI fall under $100 \%$ suitable for irrigation.

\section{Spatial distribution of physio-chemical parameters of groundwater \\ pH}

The $\mathrm{pH}$ value of natural water is a measure of its alkanity or acidity and The $\mathrm{pH}$ value is a measure of hydrogen ion concentration. The $\mathrm{pH}$ value of groundwater in study area varies from 7.3 to 8.0 with an average of 7.65 , which indicates that water is almost natural in nature.

\section{Electrical conductivity (EC)}

Conductivity is the measure of capacity of a substance to conduct the electric current. Most of the salts in water are present in their ionic forms and capable of conducting current and conductivity is a good indicator to assess groundwater quality. The EC in study area varies from 554 to 1593 with an average of $1073.5^{\mu} \mathrm{S} / \mathrm{cm}$ at $25^{\circ} \mathrm{C}$. The lowest EC in groundwater samples was observe in Bhilai and the highest in Durg. Location specific variability of EC in the block is shown by spatial variable Map.

\section{Sodium (Na)}

$\mathrm{Na}$ is the sixth most abundant element on Earth and is widely distributed in soils, plants, water and foods. Groundwater contained some $\mathrm{Na}$ because most rocks and soils contains $\mathrm{Na}$ compounds from which $\mathrm{Na}$ is easily dissolved $\mathrm{Na}$ concentration range 15.5 to $85 \mathrm{mg} / \mathrm{l}$ with an average of $50.25 \mathrm{mg} / \mathrm{l}$. 
Location specific variability of $\mathrm{Na}$ in the block is shown by spatial variable Map.

\section{Magnesium (Mg)}

$\mathrm{Mg}$ is the eighth abundant natural element. The $\mathrm{Mg}$ concentration ranges between 4 to 38 $\mathrm{mg} / \mathrm{l}$ with an average of $21 \mathrm{mg} / \mathrm{l}$. Location specific variability of $\mathrm{Mg}$ in the block is shown by spatial variable Map.

\section{Potassium (K)}

$\mathrm{K}$ is an element commonly found in soils and rocks. In water $\mathrm{K}$ has no colour or smell, but may give water a salty test. Sources of $\mathrm{K}$ include weathering and erosion of $\mathrm{K}$ bearing minirals such as feldspar and leaching of fertilizer. The $\mathrm{K}$ concentration ranges varies between 0.5 to $18.2 \mathrm{mg} / \mathrm{l}$. with an average value $9.25 \mathrm{mg} / \mathrm{l}$. Location specific variability of $\mathrm{K}$ in the block is shown by spatial variable Map.

\section{Bicarbonate $\left(\mathrm{HCO}_{3}\right)$}

The primary source of $\mathrm{HCO}_{3}$ ions in groundwater is the dissolved carbon dioxide in rain and snow, which as enters the soil dissolves more carbon dioxide. The $\mathrm{pH}$ of water indicate the form in which carbon dioxide is present in water. The $\mathrm{HCO}_{3}$ concentration ranges varies between 98 to $317 \mathrm{mg} / \mathrm{l}$. with an average of $207.5 \mathrm{mg} / \mathrm{l}$. Location specific variability of $\mathrm{HCO}_{3}$ in the block is shown by spatial variable Map.

\section{Residual sodium carbonate (RSC)}

The RSC concentration ranges vary between 11.78 to 0.72 . More than $100 \%$ sample fall under Low RSC of an area $646.8 \mathrm{~km}^{2}$. Location specific variability of RSC in the block is shown by spatial variable Map.

\section{Sodium absorption ratio (SAR)}

There is a significant relationship between SAR values of irrigation water and the extent to which sodium is absorbed by the soil. If groundwater used for irrigation is high in sodium and low in calcium, the cationexchange complex may become saturated with sodium. This can destroy the soil structure owing to dispersion of the clay particles. The SAR values ranges from 0.43 to 2.47 and according to SAR classification $100 \%$ of water sample fall in the excellent category and can be used for irrigation on almost all soils. A more detailed analysis of the suitability of water for irrigation was made by plotting the data on US Salinity Laboratory diagram.

\section{US salinity laboratory diagram}

In order to assess the US Salinity laboratory (1954) has adopted an irrigation water classification based upon SAR and EC. The C and $\mathrm{S}$ classification adhere to the description of the diagram draw on semi log paper with SAR on ordinary scale. This classification is extensively used worldwide and consists of 16 groups of irrigation water $\mathrm{C}_{1} \mathrm{~S}_{1}, \mathrm{C}_{2} \mathrm{~S}_{2}$, $\mathrm{S}_{2} \mathrm{C}_{1}, \mathrm{~S}_{2} \mathrm{C}_{2}$ etc. Based on the SAR values, all samples have low sodium hazard and on plotting over the U.S. Salinity diagram the water samples of study area fall in the $\mathrm{C}_{2} \mathrm{~S}_{1}$ classes and $\mathrm{C}_{3} \mathrm{~S}_{1}$ classes and hence can be consider suitable for irrigation with low sodium hazard and medium to high salinity hazard.

\section{Percent sodium ( $\% \mathbf{N a})$}

$\% \mathrm{Na}$ in Groundwater is an important parameter in deciding the suitability of water for irrigation as $\mathrm{Na}$ reacts with soil resulting in decreasing permeability of soil. The $\% \mathrm{Na}$ values ground water range from 10 to 45 . 
The $\% \mathrm{Na}$ values in study area fall $30 \%$ in excellent class, $60 \%$ in good and $10 \%$ in permissible class. In the present investigation, the spatial distribution map (Fig.4.9) indicates that the "Excellent" cover an aerial extent of $267.05 \mathrm{~km}^{2}$ and "Good" covers an aerial extent of $313.6 \mathrm{~km}^{2}$ and "Permissible" cover an aerial extent of $53.3 \mathrm{~km}^{2}$

\section{H. Wilcox's diagram}

Another method for determination of suitability for agricultural use in groundwater is by calculating $\% \mathrm{Na}$ (Wilcox,1955), because $\mathrm{Na}+$ concentration reacts with soil to reduce its permeability (Todd, 1980).Percentage of sodium values of groundwater samples indicate that the four groundwater samples show Excellent to Good or 6 samples Good to Permissible category for irrigation use.

\section{Suitability of groundwater for irrigation purposes}

The groundwater quality of Durg block of Durg District, Chhattisgarh has been assessed for its suitability for irrigational purposes. The study has also demonstrated the utility of GIS technology combine with laboratory analysis in evaluation and mapping of groundwater quality in block. Hydro chemical facies analysis as well the $\mathrm{pH}$ of water, both indicates that groundwater in the area is natural in condition. The electrical conductivity values of water samples are found to be within good to permissible limits during sampling sessions.

Table.1 Chemical Analysis Results (2015)

\begin{tabular}{|c|l|l|l|l|l|l|l|l|l|l|l|l|}
\hline S No. & Location & Lat. & Long. & $\mathbf{p H}$ & $\mathbf{E C}$ & $\mathbf{T H}$ & $\mathbf{N a}$ & $\mathbf{K}$ & $\mathbf{C a}$ & $\mathbf{M g}$ & $\mathbf{H C o}$ & $\mathbf{C o}_{3}$ \\
\hline $\mathbf{1}$ & Ravelidih & 21.3 & 81.3 & 7.3 & 578 & 250 & 15.5 & 0.6 & 78 & 13 & 128 & Nil \\
\hline $\mathbf{2}$ & Maroda & 21.2 & 81.3 & 7.6 & 792 & 225 & 85 & 0.7 & 50 & 24 & 317 & Nil \\
\hline $\mathbf{3}$ & Anda & 21.1 & 81.3 & 7.5 & 1400 & 525 & 58 & 4.5 & 182 & 17 & 256 & Nil \\
\hline $\mathbf{4}$ & Jeora-sirsa & 21.3 & 81.3 & 7.7 & 788 & 310 & 38 & 18.2 & 104 & 12 & 195 & Nil \\
\hline $\mathbf{5}$ & Ganiyari & 21.2 & 81.2 & 7.6 & 1127 & 465 & 21.7 & 1.3 & 122 & 38 & 244 & Nil \\
\hline $\mathbf{6}$ & Konari & 21.2 & 81.3 & 8 & 704 & 250 & 49.7 & 1 & 94 & 4 & 268 & Nil \\
\hline $\mathbf{7}$ & Durg & 21.2 & 81.3 & 7.5 & 1593 & 670 & 40 & 4 & 230 & 23 & 98 & Nil \\
\hline $\mathbf{8}$ & Utai & 21.1 & 81.4 & 7.5 & 810 & 315 & 35.9 & 0.5 & 110 & 10 & 201 & Nil \\
\hline $\mathbf{9}$ & Bhilai & 21.2 & 81.4 & 7.5 & 554 & 170 & 41.4 & 2.9 & 60 & 5 & 104 & Nil \\
\hline $\mathbf{1 0}$ & Kachandur & 21.3 & 81.3 & 7.6 & 740 & 290 & 36 & 1.5 & 68 & 29 & 250 & Nil \\
\hline
\end{tabular}

Table.2 Irrigation water quality parameters

\begin{tabular}{|c|l|c|c|c|c|c|c|c|c|}
\hline S1. & Location & pH & EC & SAR & SSP & \%Na & RSC & KI & PI\% \\
\hline $\mathbf{1}$ & Ravelidih & 7.3 & 578 & 0.43 & 11.94 & 12 & -2.87 & 0.14 & 37.61 \\
\hline $\mathbf{2}$ & Marauda & 7.6 & 792 & 2.47 & 45.23 & 45 & 0.72 & 0.83 & 73.13 \\
\hline $\mathbf{3}$ & Anda & 7.5 & 1400 & 1.1 & 19.37 & 20 & -6.3 & 0.24 & 35.1 \\
\hline $\mathbf{4}$ & Jeora-sirsa & 7.7 & 788 & 0.94 & 21.07 & 25 & -2.99 & 0.27 & 43.88 \\
\hline $\mathbf{5}$ & Ganiyari & 7.6 & 1127 & 0.44 & 9.28 & 10 & -5.23 & 0.1 & 28.94 \\
\hline $\mathbf{6}$ & Konari & 8 & 704 & 1.36 & 30.05 & 30 & -0.64 & 0.43 & 59.21 \\
\hline $\mathbf{7}$ & Durg & 7.5 & 1593 & 0.67 & 11.49 & 12 & -11.78 & 0.13 & 19.87 \\
\hline $\mathbf{8}$ & Utai & 7.5 & 810 & 0.88 & 19.8 & 20 & -3.02 & 0.25 & 42.82 \\
\hline $\mathbf{9}$ & Bhilai & 7.5 & 554 & 1.38 & 34.54 & 35 & -1.71 & 0.53 & 59.59 \\
\hline $\mathbf{1 0}$ & Kachandur & 7.6 & 740 & 0.92 & 21.29 & 22 & -1.69 & 0.27 & 48.83 \\
\hline
\end{tabular}


Table.3 Classification of Samples according to Standards specified for Water Quality Indices

\begin{tabular}{|c|c|c|c|c|}
\hline Parameters & Range & Class & Number of sample & \% of sample \\
\hline \multirow{5}{*}{ EC } & $<250$ & Excellent & 0 & 0 \\
\hline & $250-750$ & Good & 4 & 40 \\
\hline & $750-2000$ & Permissible & 6 & 60 \\
\hline & $2000-3000$ & Doubtful & 0 & 0 \\
\hline & $>3000$ & Unsuitable & 0 & 0 \\
\hline \multirow[t]{5}{*}{ SSP } & $<20$ & Excellent & 3 & 30 \\
\hline & $20-40$ & Good & 6 & 60 \\
\hline & $40-60$ & Permissible & 1 & 10 \\
\hline & $60-80$ & Doubtful & 0 & 0 \\
\hline & $>80$ & Unsuitable & 0 & 0 \\
\hline \multirow[t]{3}{*}{ RSC } & $<1.25$ & Low & 10 & 100 \\
\hline & $1.25-2.5$ & Medium & 0 & 0 \\
\hline & $>2.5$ & High & 0 & 0 \\
\hline \multirow[t]{4}{*}{ SAR } & $0-10$ & Excellent & 10 & 100 \\
\hline & $10-18$ & Good & 0 & 0 \\
\hline & $18-26$ & Permissible & 0 & 0 \\
\hline & $>26$ & Doubtful & 0 & 0 \\
\hline \multirow[t]{2}{*}{ MAR } & $\leq 50$ & Suitable & 10 & 100 \\
\hline & $>50$ & Unsuitable & 0 & 0 \\
\hline \multirow[t]{2}{*}{ KI } & $<1$ & Suitable & 10 & 100 \\
\hline & $>1$ & Unsuitable & 0 & 0 \\
\hline \multirow[t]{2}{*}{ PI } & $25 \%-75 \%$ & Suitable & 10 & 100 \\
\hline & $>75 \%$ & Unsuitable & 0 & 0 \\
\hline
\end{tabular}

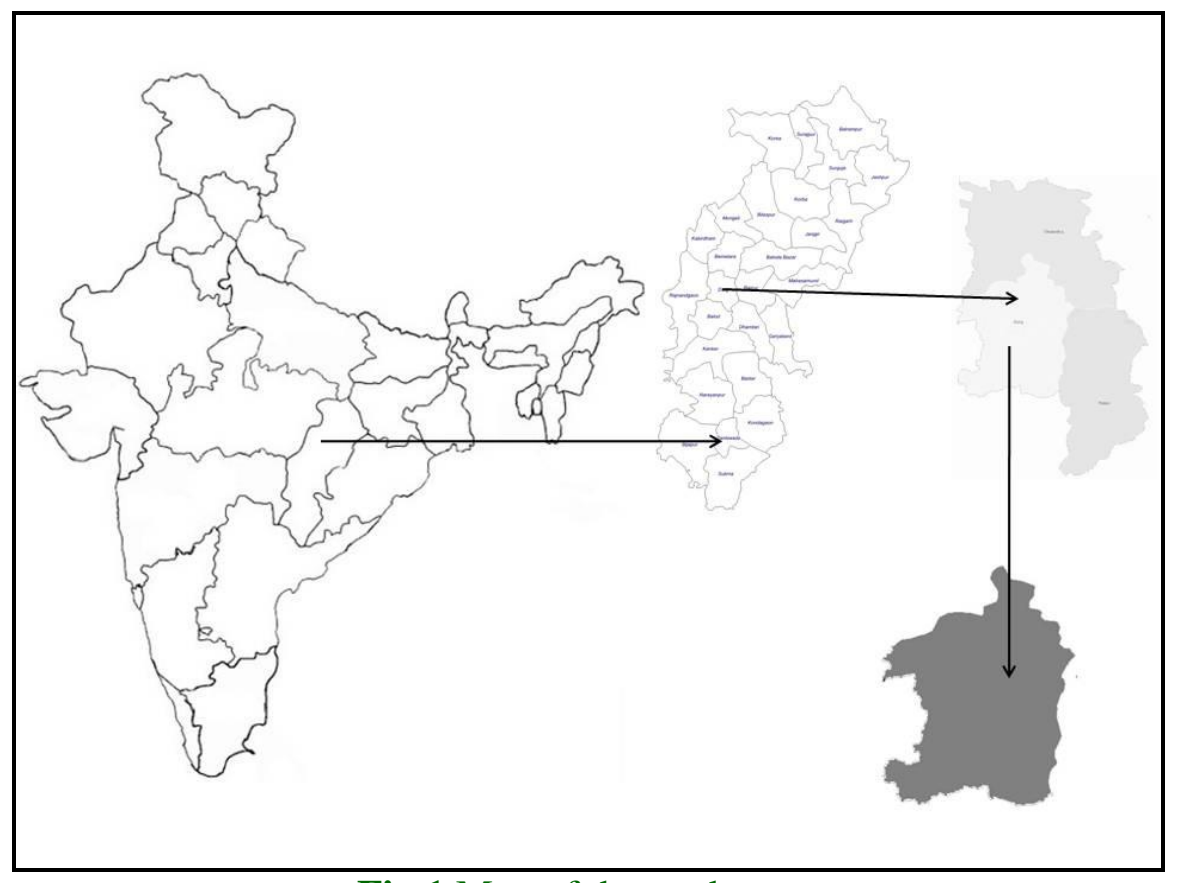

Fig.1 Map of the study area 


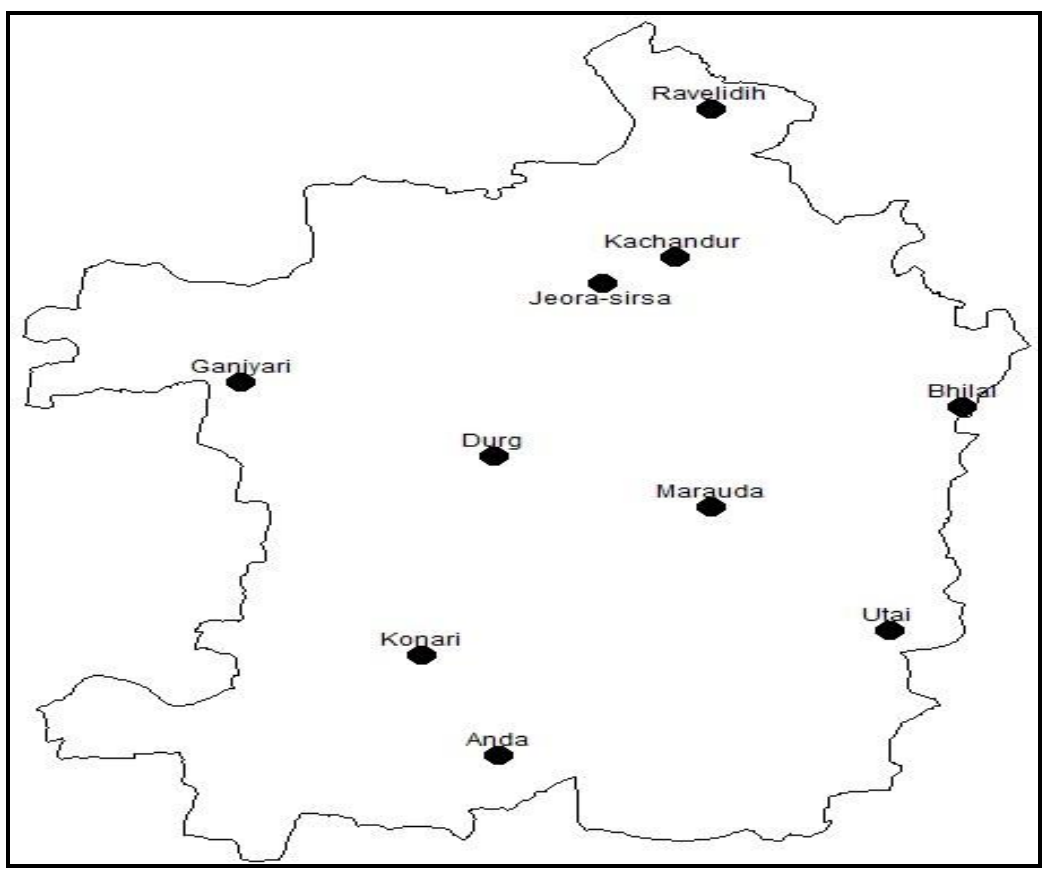

Fig.2 Location map of sampling point in Durg block

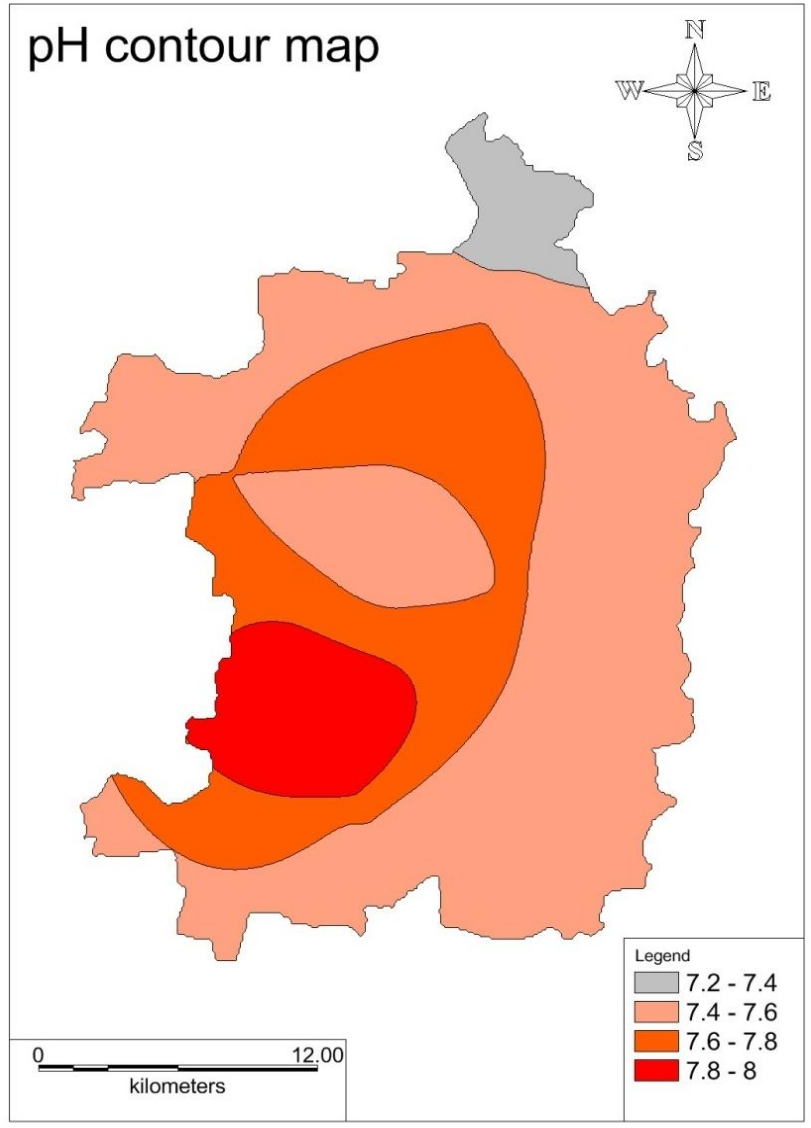

Fig.3 Spatial Distribution of $\mathrm{pH}$

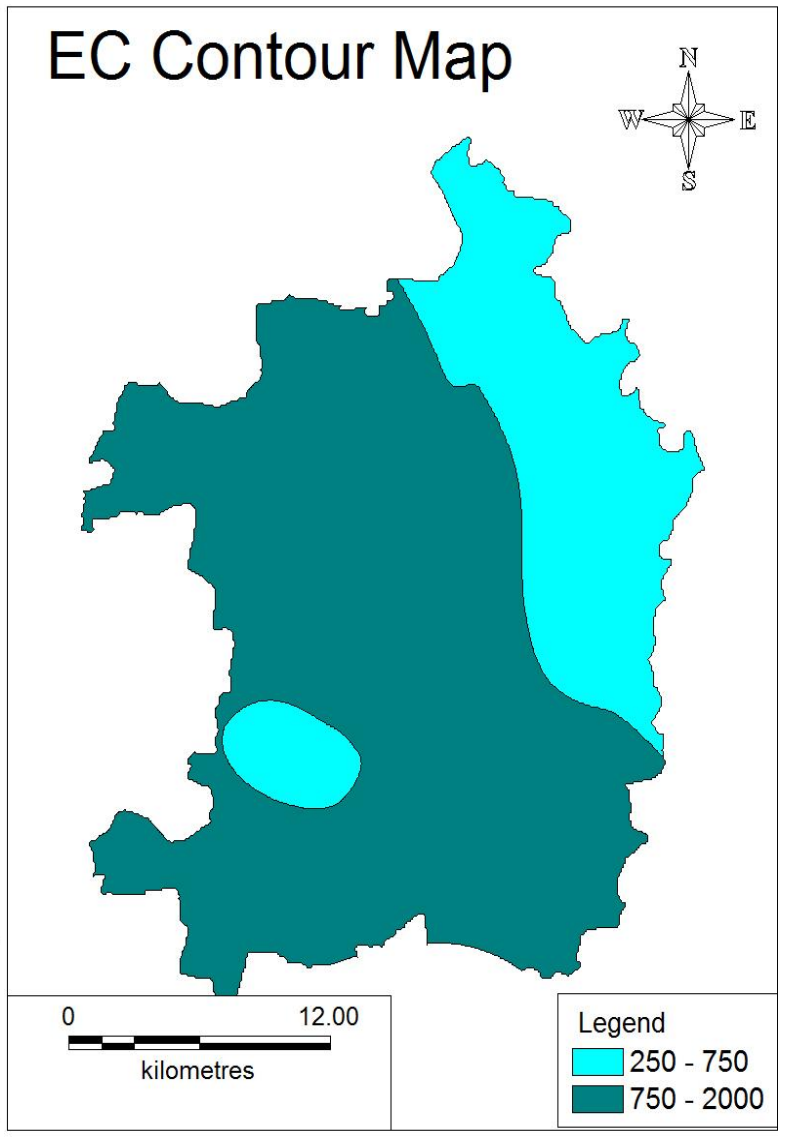

Fig.4 Spatial Distribution of EC 


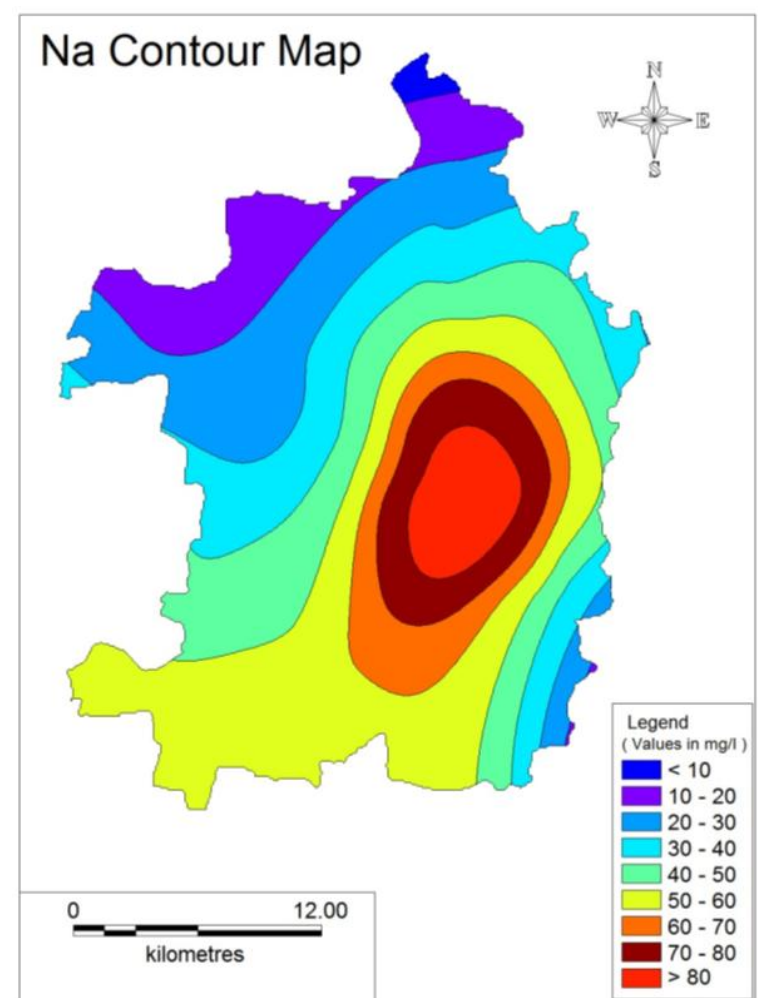

Fig.5 Spatial Distribution of $\mathrm{Na}$

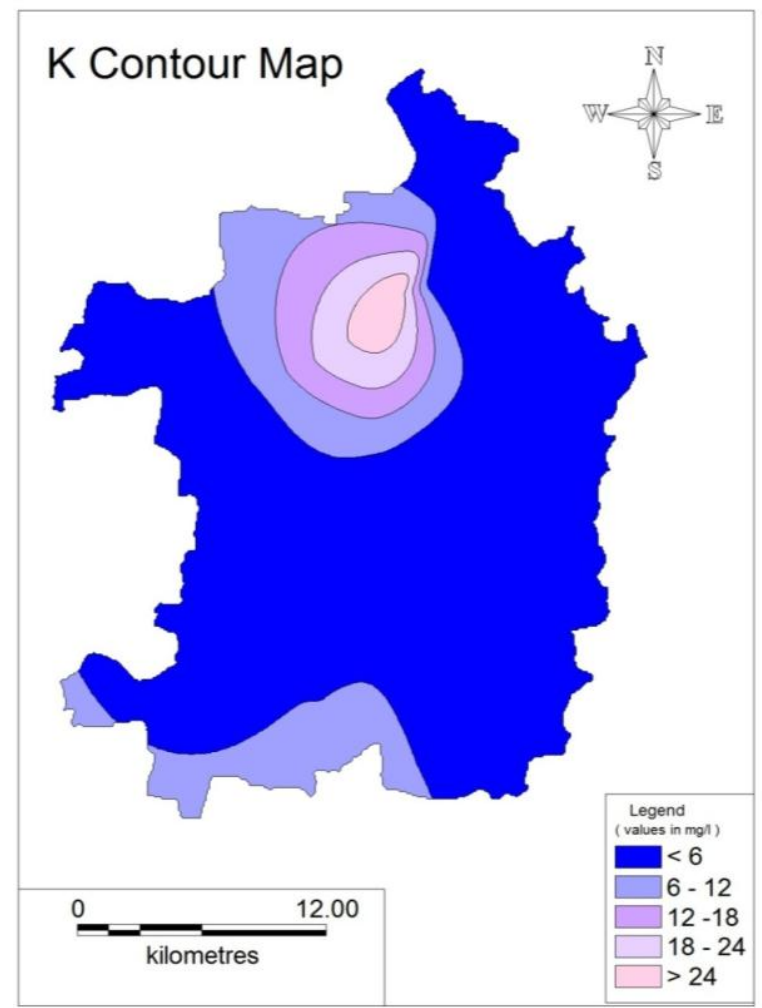

Fig.7 Spatial Distribution of K

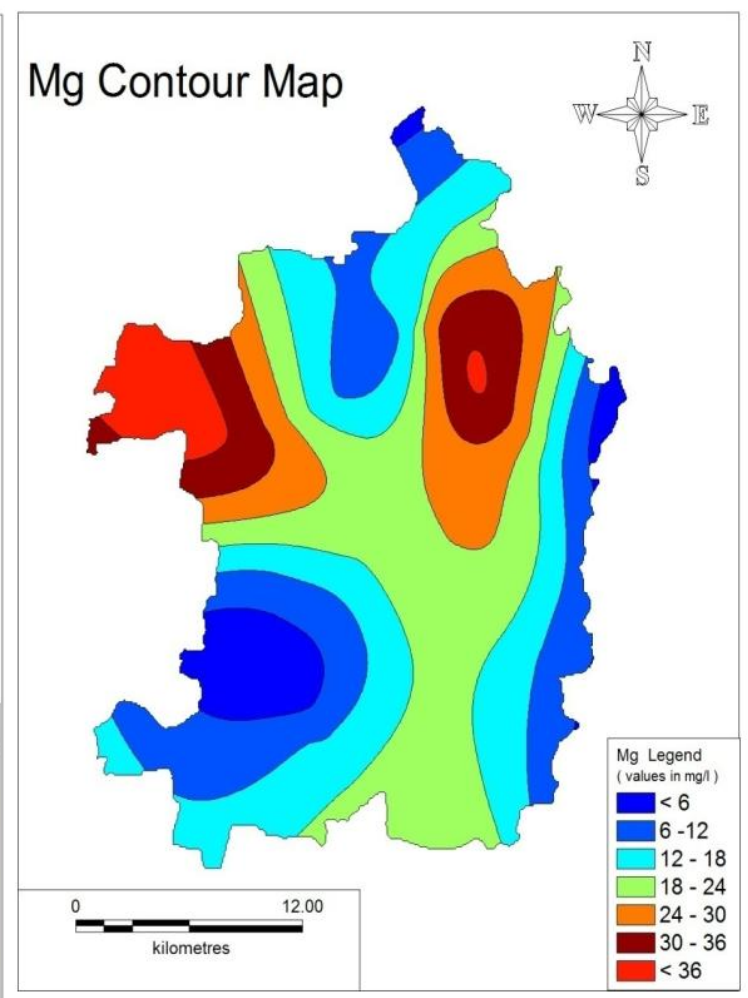

Fig.6 Spatial Distribution of Mg

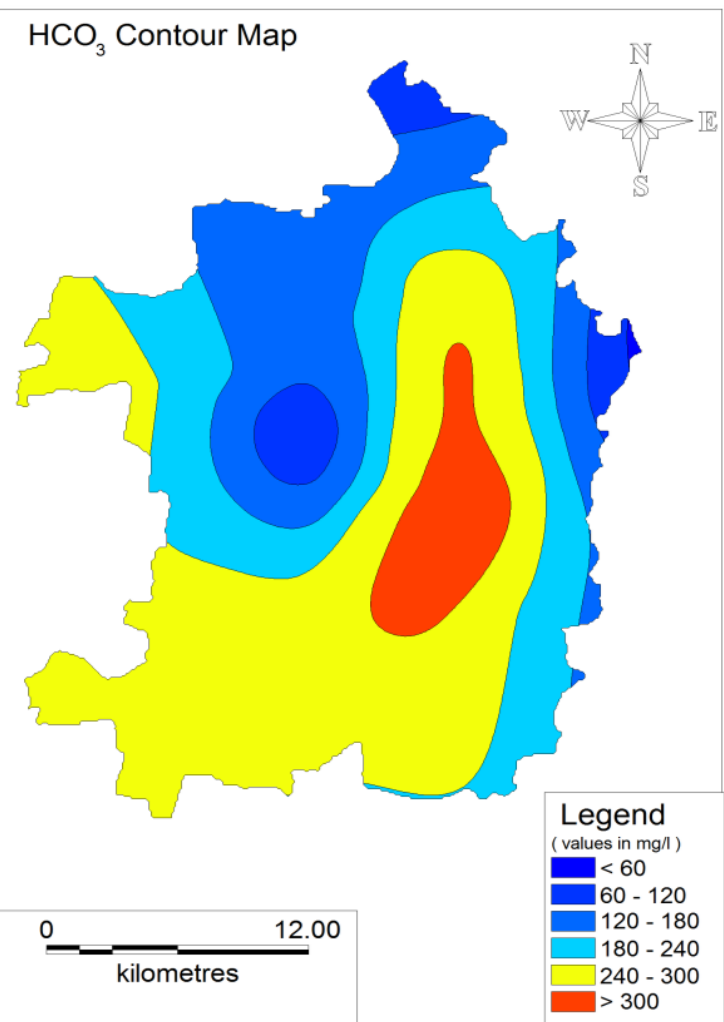

Fig.8 Spatial distribution of $\mathrm{HCO}_{3}$ 


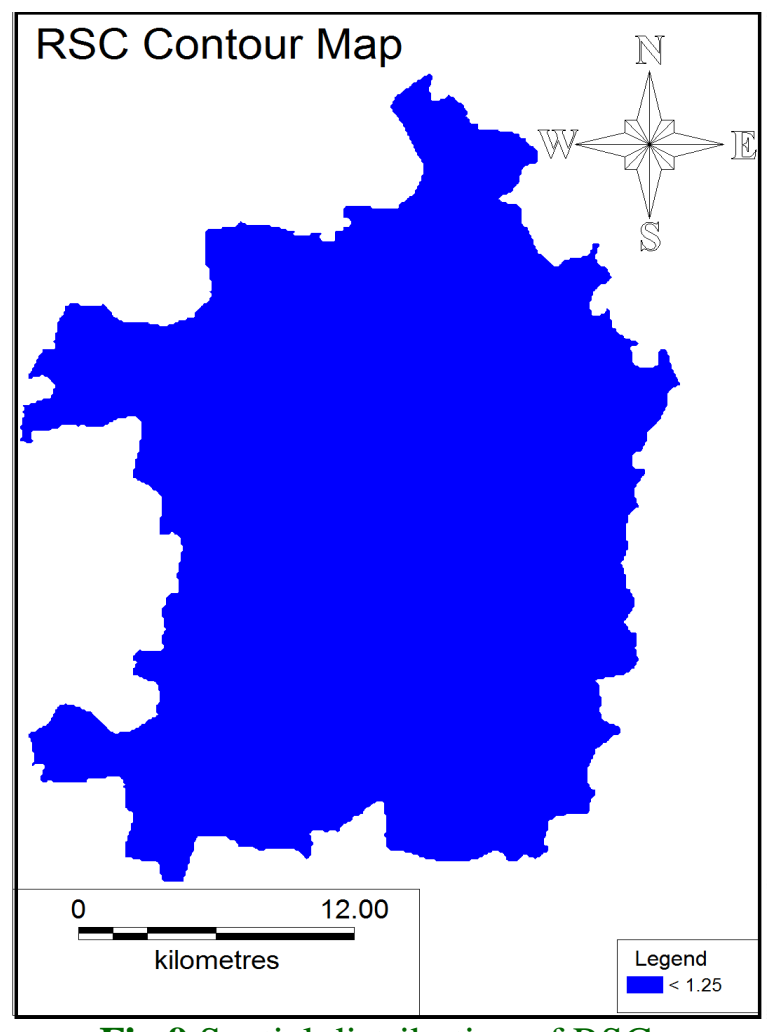

Fig.9 Spatial distribution of RSC

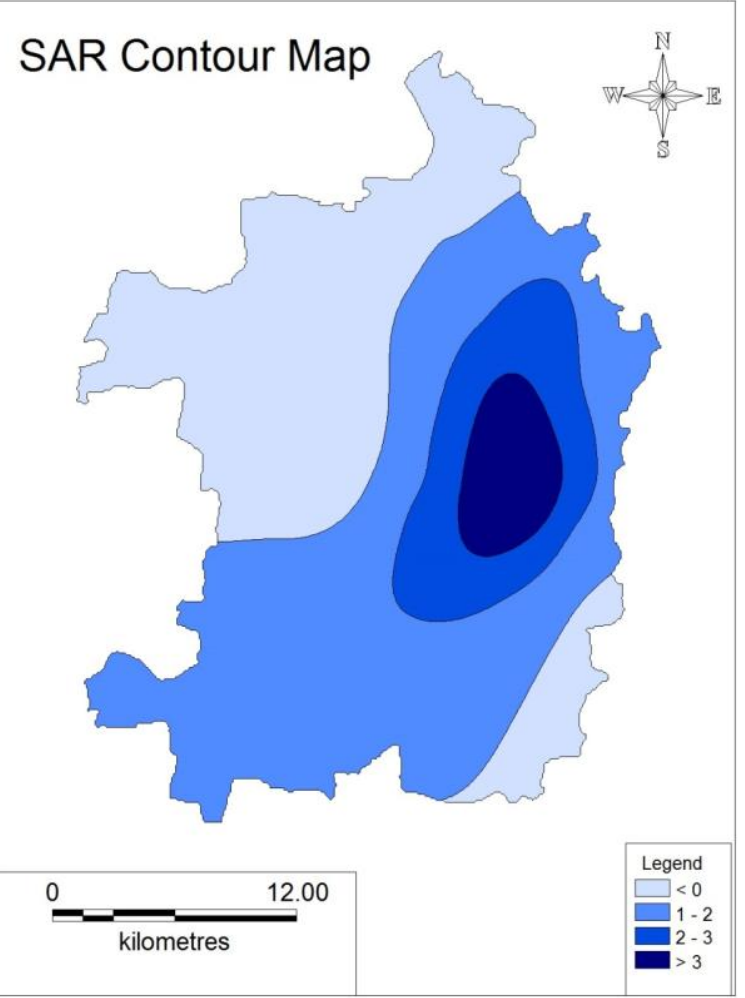

Fig.10 Spatial distribution of SAR

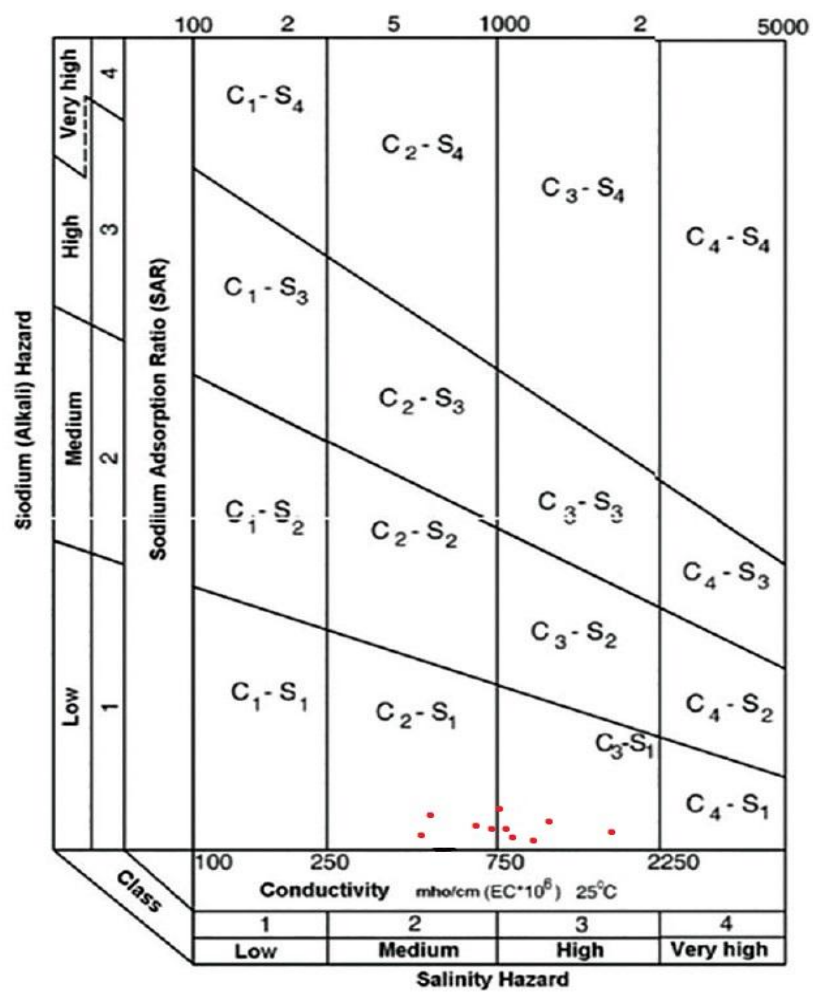

Fig.11 US Salinity Diagram 


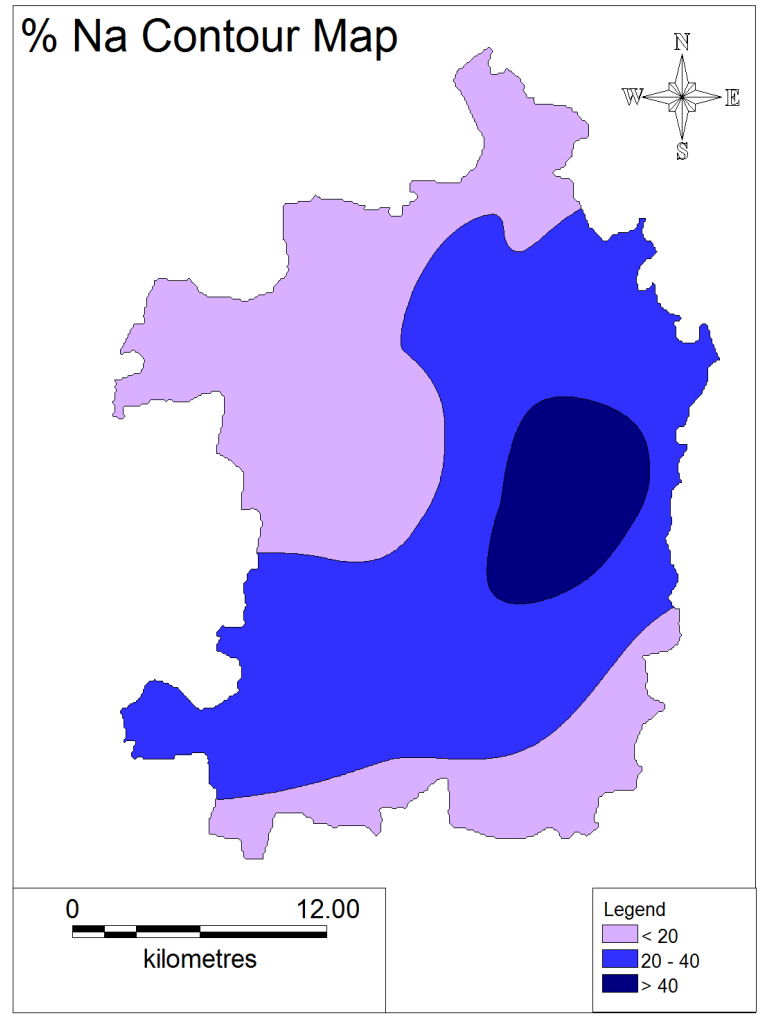

Fig.12 Spatial distribution of $\% \mathrm{Na}$

The EC in study area varies from 554 to 1593 with an average of $1073.5^{\mu} \mathrm{S} / \mathrm{cm}$. The lowest $\mathrm{EC}$ in groundwater samples was observe in Bhilai and the highest in Durg. The output of SAR shows 100 per cent of the samples fall under excellent to good category.

The irrigational water quality was classified based on US salinity diagram indicating that in 4 samples fall under $\mathrm{C}_{2}-\mathrm{S}_{1}$ class which shows low to moderate saline and 6 samples fall under $\mathrm{C}_{3}-\mathrm{S}_{1}$ class which shows low to medium high salinity. The Wilcox diagram shows 4 samples fall under excellent to good category and 6 samples fall under good to permissible category.

Based on the water quality parameters analyzed like \% Na, PI, RSC and KI the suitability of groundwater samples for irrigation is good to permissible in almost all cases.The groundwater will neither cause salinity hazards nor have an adverse effect on

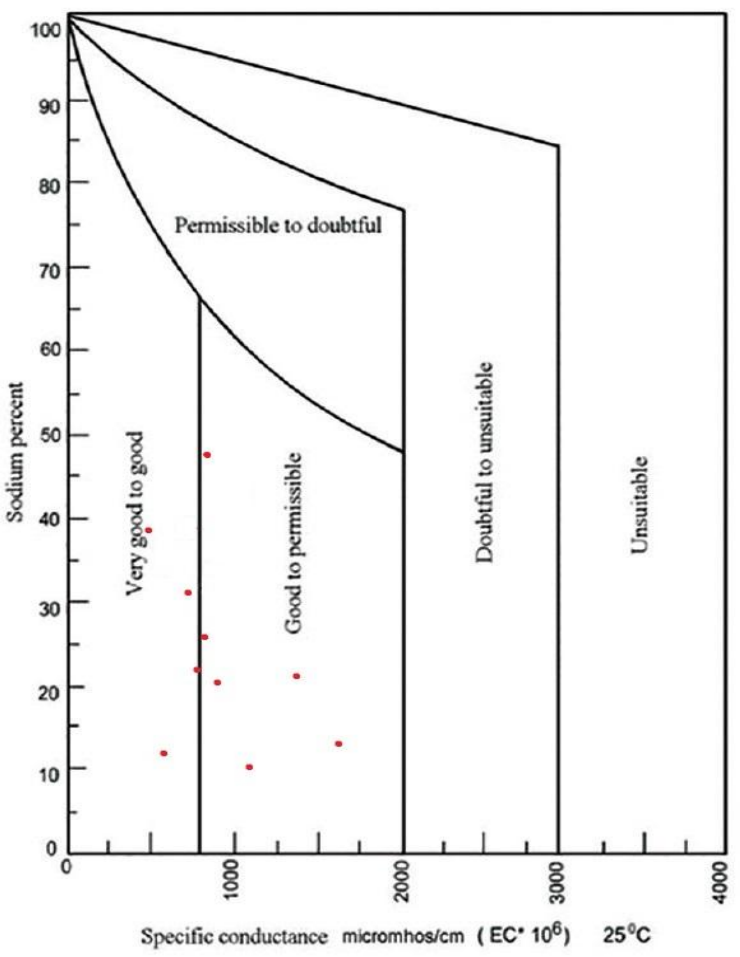

Fig.13 H. Wilcox's Diagram

the soil properties and are thus largely suitable for irrigational purpose.

\section{References}

Aghazadeh N., Mogaddam,A.A. 2010. Assessment of groundwater quality and its suitability for drinking and agricultural uses in the Oshnavieh area, Northwest of Iran, J. Environ. Prot, Vol.1, pp.30-40.

Balachandar D., Sundararaj P., Rutharvel Murthy K. , Kumaraswamy K. 2010.An Investigation of Groundwater Quality and Its Suitability to Irrigated Agriculture in Coimbatore District, Tamil Nadu, India - A GIS Approach, International journal of environment sciences, vol 1,No2, ISSN 0976 - 4402.

Balakrishnan, P., Saleem, Abdul and Mallikarjun, N. D. 2011. Groundwater quality mapping using geographic information system (GIS): A case study 
of Gulbarga City, Karnataka, India, African Journal of Environmental Science and Technology, Vol. 5(12), pp. 1069-1084,ISSN:1996-0786.

Bauder, J. W. and T.A. Brock. 2001. Irrigation water quality, soil amendment and crop effects on sodium leaching. Arid Land Res. Manage., 15:101-113.

Doneen, L.D. 1961. Notes on water quality in Agriculture. Published as a water science and Engineering Paper 4001, Department of Water Sciences and Engineering. University of California.

Durbuded. G., and Vararrajan, N. 2007. Monitoring and mapping of groundwater quality. Journal of Applied Hydrology, v.xx, No. 1\&2, pp.22-30.

Fulazzaky, M.A. 2009. Water quality evaluation system to assess the status and the suitability of the Citarum river water to different uses. Journal of Environmental Monitoring., 168, 669684.

Gupta, R.K, Singh, N.T. and Sethi, M. 1994. Water Quality for Irrigation in India. Tech. Bull. 19, CSSRI, Karnal, India.

Hakim, M.A. Juraimi, A.S., Begum, M., Hasanuzzaman, M. and Uddin, M.K. 2009. Suitability evaluation of groundwater for irrigation, drinking and industrial purposes. American Journal of Environmental Sciences., 5: 413-419.

Jeihouni, M., Toomanian, A., Shahabi, M., Alavipanah, S. K. 2014. Groundwater Quality Assessment for Drinking Purpose Using GIS Modeling. The International Archives of the Photogrammetry, International Conference on Geospatial Information Research Volume XL 2/W3-163.

K.Ambiga, Dr. R. Anna Durai 2015.Use of Geographical Information System and Water Quality Index To Assess Groundwater Quality In and Around Ranipat Area, Vellore District, Tamil Nadu, International Journal of
Advanced Engineering Research and Studies, ISSN:2249-8974.

Kumar, Sanjay, Sharma, S.K., Satyavan, and Sharma, Ramesh 2014. GIS Mapping of Groundwater Quality of Bahadurgarh Block of Jhajjar District, Journal of soil and water conservation, 13(2):134 - 139 ISSN:022 - 457.

Meireles, A.C.M., E.M. Andrade, L.C.G. Chaves, H. Frischkorn and L.A. Crisóstomo 2010. A new proposal of the classification of irrigation water RevistaCienciaAgronomica, 41(3): 349357. 37(17): 4119-4124.

Michael, A.M. and Ojha, T.P. 2013. Principle of agriculture Engineering vol-2, Jain Brothers New Delhi. 20:1059-1065.

Michael, A.M., 2007. Irrigation: Theory and Practice, Vikas Publishing House Pvt. Ltd., New Delhi, 14:661-694.

Nag, S.K. , Das, shreaya 2014. Groundwater Quality for Irrigation And Domestic Purpose - A GIS Based Case Study of Suri I And II Block, Birbhum District, West Bengal, India.International Journal of Advancement in Earth and Environmental Sciences, IJAEES (2014) Vol.2, No.1, 25-38 ISSN: 2321 -9149 .

Prabhjot Singh Bhuie, 2008. Analysis of shoreline changes in the coastal region of west Bengal using image processing and photogrammetric techniques. $\mathrm{M}$. Tech. thesis Report, Department of Remote sensing, Birla Institute of technology, MESRA-835215, RANCHI, pp. 72-75.

Ramakrishnaiah, C.R., C. Adashiv and G.Ranganna 2009. Assessment of Water Quality Index for the Groundwater in Tumkur Taluk, Karnataka State, India. European Journal of Organic Chemistry, 6: 523-530.

S, Nair, Archana, M., April 2004. Geographic Information System and groundwater quality mapping in Panvel Basin, 
Maharashtra, India, Journal Environmental Geology, Volume 45, Issue 6 ISSN:0943-0105, pp 756-76.

Shah, S. M. and Mistry, N. J. 2013. Groundwater Quality Assessment for Irrigation Use in Vadodara District, Gujarat, India World Academy of Science, Engineering and Technology, Vol:7 2013-07-23.

Shihab, A.S., Al-Rawi, S.M. 1994. Application of water quality index to Tigris River within Mosul city. Rafidain,J. Sci., 4, 80-92.

Sinha, A.K., Kumar, Vinay and Singh, P.K., 2018. International Journal of Current Microbiology and Applied Sciences, ISSN: 2319-7706 Special Issue-7 pp. 1313-1332.

Subramani, T, Krishnan P.S., Kuaresan, K.P. may-June 2012, Study of Groundwater Quality with GIS Application for
Coonoor Taluk in Nilgiri

District,International Journal of Modern Engineering Research (IJMER),Vol.2, Issue.3, pp-586-592 ISSN: 2249-6645.

Suresh T.S., Naganna C., Srinivas, G. 1991. Study of water quality for agricultural use in Hemavathy river (Karnataka) Hydrology.Journal Indian Association Hydrology, 14(4):247-254.

Todd, D.K. 1980. Ground Water Hydrology, Jhon Velly and sons Pvt. Ltd New York. 7:267-291.

Wilcox, L.V 1955. Classification and use of irrigation waters. US Department of Agriculture, Arc 969, Washington DC.

Yammani , S. 2006. Groundwater quality suitable zones identification: application of GIS, Chittoor area, Andhra Pradesh, India, Environ Geol-634-1.

\section{How to cite this article:}

Lov Kumar Gupta, Kapil Verma and Shruti Verma. 2020. Suitability of Groundwater Quality for Irrigation Purpose using Geographical Information System: A Case Study of Durg Block Chhattisgarh. Int.J.Curr.Microbiol.App.Sci. 9(05): 1564-1576. doi: https://doi.org/10.20546/ijcmas.2020.905.177 